\title{
Front Matter: Volume 11358
}

, "Front Matter: Volume 11358," Proc. SPIE 11358, Nonlinear Optics and its Applications 2020, 1135801 (11 May 2020); doi: 10.1117/12.2571908

SPIE. Event: SPIE Photonics Europe, 2020, Online Only 


\title{
Nonlinear Optics and its Applications 2020
}

\author{
Neil G. R. Broderick \\ John M. Dudley \\ Anna C. Peacock \\ Editors \\ 6-10 April 2020 \\ Online Only, France \\ Sponsored by \\ SPIE \\ Cosponsored by \\ City of Strasbourg (France) \\ Eurometropole (France) \\ CNRS (France) \\ Région Grand Est (France) \\ iCube (France) \\ Université de Strasbourg (France) \\ Cooperating Organisations \\ Photonics 21 (Germany) \\ EOS-European Optical Society (Germany) \\ Photonics Public Private Partnership (Belgium) \\ Photonics France (France) \\ Published by \\ SPIE
}


The papers in this volume were part of the technical conference cited on the cover and title page. Papers were selected and subject to review by the editors and conference program committee. Some conference presentations may not be available for publication. Additional papers and presentation recordings may be available online in the SPIE Digital Library at SPIEDigitalLibrary.org.

The papers reflect the work and thoughts of the authors and are published herein as submitted. The publisher is not responsible for the validity of the information or for any outcomes resulting from reliance thereon.

Please use the following format to cite material from these proceedings:

Author(s), "Title of Paper," in Nonlinear Optics and its Applications 2020, edited by Neil G. R. Broderick, John M. Dudley, Anna C. Peacock, Proceedings of SPIE Vol. 11358 (SPIE, Bellingham, WA, 2020) Seven-digit Article CID Number.

ISSN: 0277-786X

ISSN: 1996-756X (electronic)

ISBN: 9781510634886

ISBN: 9781510634893 (electronic)

Published by

SPIE

P.O. Box 10, Bellingham, Washington 98227-0010 USA

Telephone +1 3606763290 (Pacific Time) · Fax +1 3606471445

SPIE.org

Copyright (C) 2020, Society of Photo-Optical Instrumentation Engineers.

Copying of material in this book for internal or personal use, or for the internal or personal use of specific clients, beyond the fair use provisions granted by the U.S. Copyright Law is authorized by SPIE subject to payment of copying fees. The Transactional Reporting Service base fee for this volume is $\$ 21.00$ per article (or portion thereof), which should be paid directly to the Copyright Clearance Center (CCC), 222 Rosewood Drive, Danvers, MA 01923. Payment may also be made electronically through CCC Online at copyright.com. Other copying for republication, resale, advertising or promotion, or any form of systematic or multiple reproduction of any material in this book is prohibited except with permission in writing from the publisher. The CCC fee code is 0277$786 \mathrm{X} / 20 / \$ 21.00$.

Printed in the United States of America by Curran Associates, Inc., under license from SPIE.

Publication of record for individual papers is online in the SPIE Digital Library.

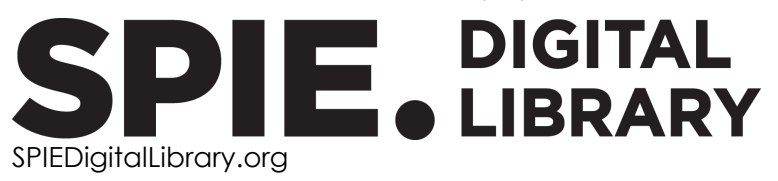

Paper Numbering: Proceedings of SPIE follow an e-First publication model. A unique citation identifier (CID) number is assigned to each article at the time of publication. Utilization of CIDs allows articles to be fully citable as soon as they are published online, and connects the same identifier to all online and print versions of the publication. SPIE uses a seven-digit CID article numbering system structured as follows:

- The first five digits correspond to the SPIE volume number.

- The last two digits indicate publication order within the volume using a Base 36 numbering system employing both numerals and letters. These two-number sets start with 00, 01, 02, 03, 04, $05,06,07,08,09,0 A, 0 B \ldots$. OZ, followed by 10-1Z, 20-2Z, etc. The CID Number appears on each page of the manuscript. 


\section{Contents}

$\begin{array}{ll}\text { vii } & \text { Authors } \\ \text { ix } & \text { Conference Committee }\end{array}$

APPLICATIONS OF NONLINEAR PHOTONICS

1135802 Single nanoparticle detection in the far field by nonlinear optical method [1 1358-2]

$1135803 \quad$ Evanescent Kerr effect in liquid-immersed optical nanofibers [11358-3]

NONLINEAR DYNAMICS AND INSTABILITIES

1135805 Temporal imaging of ultrafast signals in time and space simultaneously [11358-5]

1135806 Optical bistability and frequency combing in silicon edge defect photonic crystals [1 1358-6]

1135807 Simultaneous transition from continuous to pulsed and from PT-symmetric to PT-broken generation in coupled fiber lasers [11358-7]

NONLINEAR SEMICONDUCTOR PHOTONICS

11358 OD Optical push broom in a silicon waveguide [11358-13]

$11358 \mathrm{OF}$ Generation of damped sinusoidal and ultra-wideband microwave waveforms based on an optoelectronic approach [11358-15]

NONLINEAR MATERIAL SYSTEMS

11358 Ol Slow light using photorefractive nonlinear optics [1 1358-18]

ULTRAFAST MEASUREMENT AND CHARACTERIZATION

$1135800 \quad$ Numerical modelling of WGM microresonator Kerr frequency combs in self-injection locking regime [11358-24]

$113580 Q \quad$ Dissipative Kerr soliton generated in a ring resonator with optical feedback [1 1358-26] 
11358 OR Ultrafast rogue waves in a vector field [1 1358-27]

NONLINEAR AND ULTRAFAST DYNAMICS I: JOINT SESSION

11358 OT Forecasting the amplitude of high-intensity chaotic laser pulses [1 1358-29]

NONLINEAR AND ULTRAFAST DYNAMICS II

11358 OX Reproducing complex explosion and intermittence dynamics in a dissipative soliton laser using a scalar iterative map [11358-33]

$113580 Z$ Temporal Arago spot in optical fibers [11358-35]

$1135810 \quad$ Correlation of solitons in bidirectional mode-locked fibre laser [1 1358-36]

\section{POSTER SESSION}

1135818 THz generation by optical rectification for a novel shot-to-shot synchronization system between electron bunches and femtosecond laser pulses in a plasma wakefield accelerator [1 1358-45]

1135819 Triangular spectral phase tailoring for the generation of high-quality picosecond pulse trains [1 1358-46]

$113581 \mathrm{~A}$ Intraband FWM effect and its impacts in an ultra-long single-span 10Gbps SDH system [1 1358-47]

11358 1B Characterization of coherent structures in dissipative systems using nonlinear Fourier transform [1 1358-48]

11358 1C Ultrafast third-order nonlinear optical properties of a novel 4-methoxy-4'-nitro chalcone by z-scan and degenerate four-wave mixing techniques [11358-49]

$113581 \mathrm{E} \quad$ Spatio-temporal localization of the intense pulses in the multiphoton ionization regime [11358-51]

$11358 \mathrm{lF} \quad$ Comparative analysis of the efficiency of fixing methods of metal-doped silica nanoparticles by laser-induced breakdown spectroscopy [1 1358-52]

$113581 \mathrm{H} \quad$ Front induced transitions: refractive index fronts in dispersive waveguides [11358-54]

$1135811 \quad$ Two-color platicons in quadratically nonlinear optical microresonators [1 1358-55]

$113581 \mathrm{~N} \quad$ Time-lenses placed in an array with overlapping between adjecent time-lenses [11358-60] 
1135810 Temporal imaging system based on four-wave mixing interaction which does not require synchronization to a pump wave [11358-61]

$113581 Q \quad$ Nonlinear optical properties of mirror-image configurations of chiral limonene molecule [11358-64]

11358 IR SOA-aided photonic signal generation for hybrid fibre and FSO 5G transmission links [1 1358-65]

11358 is Highly-resolved (2+1) nonlinear resonantly-enhanced multiphoton ionization of supersonically jet-cooled $\mathrm{H}_{2} \mathrm{O}$ and $\mathrm{D}_{2} \mathrm{O}$ molecules [11358-66]

$113581 \mathrm{U} \quad$ Monitoring of photopolymerization induced changes of self-written waveguides [11358-68]

11358 IW Stabilizing optical vortex bullets by absorption at quadratic nonlinearity [11358-71]

$113581 \mathrm{X} \quad$ Method of information productivity increasing for efficient acousto-optic processors of spectral type [11358-72]

$1135812 \quad$ Quadratic chirped optical soliton at the concurrency of the dispersion of different orders [1 1358-75]

1135820 Optical rectification at second-order dispersion close to zero [11358-76]

$1135821 \quad$ Optical bullets in media with quadratic nonlinearity at the competition of second-and thirdorder dispersions [1 1358-77]

1135822 Jitter suppression in passive harmonic mode-locking fiber ring laser [11358-78]

1135824 Control of a Brillouin microresonator laser through detuning effects [11358-80]

1135825 Inertialess and resonance nonlinearity in colloidal CdSe/ZnS quantum dots in the case of twophoton excitation of excitons [11358-81] 
Proc. of SPIE Vol. 11358 1135801-6

\section{Downloaded From: https://www.spiedigitallibrary.org/conference-proceedings-of-spie on 26 Apr 2023
Terms of Use: https://www.spiedigitallibrary.org/terms-of-use}




\section{Authors}

Numbers in the index correspond to the last two digits of the seven-digit citation identifier (CID) article numbering system used in Proceedings of SPIE. The first five digits reflect the volume number. Base 36 numbering is employed for the last two digits and indicates the order of articles within the volume. Numbers start with 00, 01, 02, 03, 04, 05, 06, 07, 08, 09, OA, OB...0Z, followed by 10-12, 20-2Z, etc.



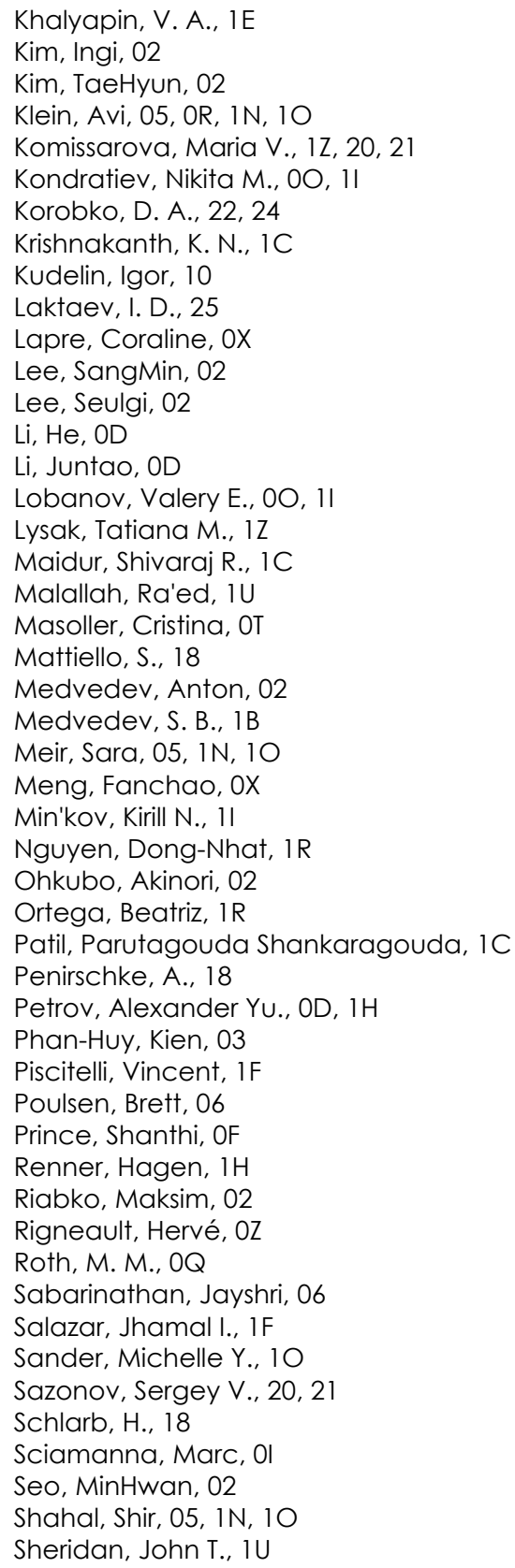


Shitikov, Artem E., 11

Shorokhov, Aleksandr, 02

Shtyrina, O. V., 1B

Sibony, Inbar, 05, 1N, 10

Smirnov, A. M., 25

Smirnov, Sergey V., 07

Sofronov, Anton, 02

Soriano, Miguel C., OT

Sugavanam, Srikanth, 10

Sylvestre, Thibaut, 03

Turitsyn, S. K., 1B

Vallejo, Luis, IR

Venugopal Rao, S., 1C

Voloshin, Andrey S., 00

Wolfersberger, Delphine, 01

Yoo, Hosun, 02

Zagursky, Dmitry Yu., IW

Zaichenko, K. V., IX

Zajnulina, M., 22

Zakharova, Irina G., 1W, 1Z, 20, 21

Zhu, Xiaobo, IA

Zolotovskii, I. O., 22, 24

Zvanovec, Stanislav, IR

Zylstra, Michael, 06 


\title{
Conference Committee
}

\author{
Symposium Chairs
}

Francis Berghmans, Vrijie Universiteit Brussel (Belgium)

Thierry Georges, Oxxius SA (France)

Paul Montgomery, Université de Strasbourg (France)

Lluis Torner, ICFO Barcelona (Spain)

Conference Chairs

Neil G. R. Broderick, The University of Auckland (New Zealand)

John M. Dudley, Institut Franche-Comte Electronique Mecanique Thermique et Optique (France)

Anna C. Peacock, University of Southampton (United Kingdom)

Conference Programme Committee

Ole Bang, Technical University of Denmark (Denmark)

Fabio Biancalana, Heriot-Watt University (United Kingdom)

Camille Brès, Ecole Polytechnique Fédérale de Lausanne

(Switzerland)

Zhigang Chen, Nankai University (China)

Benjamin J. Eggleton, The University of Sydney (Australia)

Mark Foster, Johns Hopkins University (United States)

Moti Fridman, Bar-llan University (Israel)

Goëry Genty, Tampere University of Technology (Finland)

Rachel Grange, ETH Zurich (Switzerland)

Kathy Lüdge, Technische Universität Berlin (Germany)

Cristina Masoller, Universitat Politècnica de Catalunya (Spain)

Arnaud Mussot, Laboratoire de Physique des Lasers, Atomes et Molécules (France)

Michelle Y. Sander, Boston University (United States)

Dawn T. H. Tan, Singapore University of Technology \& Design

(Singapore)

Giovanna Tissoni, Institut de Physique de Nice (France)

\section{Session Chairs}

1 Applications of Nonlinear Photonics

Anna C. Peacock, University of Southampton (United Kingdom)

2 Nonlinear Dynamics and Instabilities

Bernd Krauskopf, The University of Auckland (New Zealand) 
3 Quantum and Cavity Dynamics

Neil G. R. Broderick, The University of Auckland (New Zealand)

4 Nonlinear Semiconductor Photonics

Birgit Stiller, Max-Planck-Institut für die Physik des Lichts (Germany)

5 Nonlinear Material Systems

Frédérique Vanholsbeeck, The University of Auckland (New Zealand)

6 Ultrafast Measurement and Characterization

John M. Dudley, Institut Franche-Comte Electronique Mecanique Thermique et Optique (France)

$7 \quad$ Nonlinear and Ultrafast Dynamics I: Joint Session

John C. Travers, Heriot-Watt University (United Kingdom)

8 Nonlinear and Ultrafast Dynamics II

Jeffrey Moses, Cornell University (United States)

9 Nonlinear and Ultrafast Dynamics III

Roberto Morandotti, Institut National de la Recherche Scientifique (Canada) 